\title{
PENERAPAN TEKNIK TOKEN ECONOMY UNTUK MENINGKATKAN KEMANDIRIAN ANAK TK KARTIKA IV-21 MADIUN
}

\author{
Muh. Chotim, Noviyanti Kartika Dewi, Silvia Yula Wardani, \& Ratih \\ Christiana.
}

\begin{abstract}
ABSTRAK
Anak usia TK adalah anak yang sedang berada pada rentang usia 4-6 tahun, yang merupakan sosok individu yang sedang dalam proses perkembangan. Anak usia TK ini memiliki karakteristik dan kepribadian masing-masing serta yang lebih unik adalah anak memiliki dunianya sendiri. Adapun karakteristik anak usia TK adalah kurang mandiri, pemalu, pendiam, penakut, bergantung pada orang tua dan guru, takut untuk salah. Penerapan token economy dirasa mampu dalam meningkatkan kemandirian siswa TK Kartika IV-21 Kota Madiun.

Terkait dengan perilaku mandiri dapat dikatakan sebagai kemampuan untuk mengendalikan dan mengatur pikiran, perasaan dan tindakan sendiri secara bebas serta berusaha sendiri untuk mengatasi perasaan-perasaan malu dan keraguraguan. Kemandirian biasanya ditandai dengan kemampuan menentukan nasib sendiri, kreatif dan inisiatif, mengatur tingkah laku, bertanggung jawab, mampu menahan diri, membuat keputusan sendiri, serta mampu mengatasi masalah tanpa ada pengaruh dari orang lain. Hal inilah yang dapat digunakan menjadi alternatif yang relevan untuk menangani anak yang berperilaku kurang mandiri diantaranya digunakan teknik token economy.

Token economy dapat digunakan sebagai penguat yang dapat bertahan lama, ada beberapa keuntungan yang didapatkan dari token economies yaitu, Pertama, mereka dapat diberikan segera sesudah suatu perilaku yang diinginkan terjadi dan dipertukarkan diwaktu mendatang dengan backup reinforcers.

Penelitian ini menggunakan pendekatan deskriptif eksperimen. Berdasarkan penelitian yang dilakukan di TK Kartika IV-21Kota Madiun diperoleh gambaran bahwa anak usia TK di TK Kartika IV-21Kota Madiun tersebut cenderung menunjukkan perilaku kurang mandiri. Hal ini terlihat dari lembar observasi kemandirian yang dilakukan oleh peneliti dan juga berdasarkan wawancara yang dilakukan terhadap orang tua dan guru siswa.

Berdasarkan hasil observasi yang dilakukan sebanyak 3 kali yaitu mulai Berdasarkan kegiatan observasi yang dilakukan, dapat disimpulkan bahwa tingkat kemandirian anak TK Kartika IV-21 Kota Madiun masih rendah. Berangkat dari data tersebut peneliti melakukan perlakuan dengan menerapkan teknik token economy. Berdasarkan hasil observasi yang dilakukan peneliti seteah perlakuan diketahui bahwa kemandirian anak menjadi 41, 35\% dan diketegorikan cukup mandiri. Sehingga dapat disimpulkan bahwa teknik token economy dapat meningkatkan kemandirian anak TK kartika IV-21 Kota Madiun.
\end{abstract}

Kata Kunci: Token Economy, Kemandirian 


\section{PENDAHULUAN}

Saat ini kemandirian menjadi permasalahan tersendiri bagi seorang pendidik dan orang tuanya. Banyak anak-anak yang berusia 5-6 tahun yang idealnya sudah bisa belajar hidup mandiri, tidak manja, tidak cengeng, dan berani belajar sendiri tanpa harus didampingi setiap hari disekolah. Namun kenyataannya masih banyak anak yang belum mandiri, penakut, manja, cengeng, pemalu dan tidak mau ditinggal orang tuanya. Apabila hal ini dibiarkan saja, tentu saja akan sangat berpengaruh pada perkembangan anak selanjutnya, bahkan apabila tidak dilatih dan dibiasakan untuk hidup mandiri sejak dini maka anak akan mengalami kesulitan pada perkembangan dia selanjutnya.

Kemandirian anak usia dini berbeda dengan kemandirian remaja ataupun orang dewasa. Jika definisi mandiri untuk remaja dan orang dewasa adalah kemampuan seseorang untuk bertanggung jawab atas apa yang dilakukan tanpa membebani orang lain, sedangkan untuk anak usia dini adalah kemampuan yang disesuaikan dengan tugas perkembangan. Adapun tugas-tugas perkembangan untuk anak usia dini adalah, belajar makan, berlatih berbicara, koordinasi tubuh, kontak perasaan dengan lingkungan, pembentukan pengertian, dan belajar moral. Apabila seorang anak usia dini telah mampu melakukan tugas perkambangan tersebut berarti ia telah memenuhi syarat kemandirian.

Permasalahan tentang kemandirian ini banyak ditemukan di TK Kartika IV21. Berdasarkan informasi yang diperoleh para guru dan orang tua sering mengeluhkan tentang anaknya yang kurang bisa mandiri dalam melakukan ataupun memenuhi kebutuhannya sendiri seperti memakai baju, memakai sepatu, menyiapkan buku pelajarannya dan lain sebagainya. Banyak orang tua yang merasa khawatir dengan perilaku anaknya tersebut.

Berdasarkan permasalahan yang dikemukakan di atas peneliti mencoba untuk menerapkan teknik Token Economies dalam meningkatkan kemandirian anak di TK Kartika IV-21. Teknik ini dipandang sesuai untuk mengatasi permasalahan diatas, diharapkan dengan penggunaan teknik Token Economies ini mampu meningkatkan tingkat kemandirian anak anak TK Kartika IV-21. 
Berdasarkan latar belakang di atas, maka dalam penelitian ini dapat dikemukakan rumusan masalah sebagai berikut: 1. Bagaimanakah penerapan teknik token ekonomy untuk meningkatkan kemadirian anak di TK Kartika IV21Madiun; 2. Bagaimanakah keefektifan teknik token ekonomy untuk meningkatkan kemadirian anak di TK Kartika IV-21Madiun?

\section{A. TINJAUAN PUSTAKA}

\section{A. Token Economies}

\section{Pengertian Token Economies}

Dalam buku Behavior Modification: What It Is and How to Do It, oleh Garry Martin dan Joseph Pear pada tahun 1992, pada intinya token economieses dapat digunakan sebagai penguat yang dapat bertahan lama, ada beberapa keuntungan yang didapatkan dari token economies yaitu, Pertama, mereka dapat diberikan segera sesudah suatu perilaku yang diinginkan terjadi dan dipertukarkan diwaktu mendatang dengan backup reinforcers.

John W Santrock (1995:128) menyatakan Token Economies atau tabungan kepingan adalah pemberian satu kepingan (atau satu tanda, satu isyarat) sesegera mungkin setiap kali setelah perilaku sasaran muncul. Kepingan-kepingan ini nantinya dapat ditukar dengan benda atau aktivitas pengukuh yang diingini oleh subyek.

Stephen Palmer (2011:87) menyatakan bahwa Token economies adalah penerapan operant conditioning dengan mengganti hadiah langsung dengan sesuatu yang dapat ditukarkan kemudian. Disebut operant karena memberikan perlakuan terhadap lingkungan yaitu berupa hadiah kepada tingkah laku. Dengan adanya hadiah perilaku akan terus berulang atau muncul. Pemberian hadiah atau ganjaran bukan jawaban atas semua masalah perilaku anak. Yang akan dinyatakan di sini adalah bahwa hadiah atau ganjaran agaknya sangat berguna dalam mengatasi beberapa kesulitan akibat hiperaktivitas. 
Metode token economy dikembangkan oleh Ayllon dan Azrin (dalam Indrijati, 2002 hal.9). Konsep token economy adalah pemberian reinforcement yang langsung terhadap perilaku sesuai dengan yang ditentukan dalam aturanaturan dalam kelas. Menurut Indrijati (2002, h.10), metode token economy ini efektif pada seluruh tingkat usia. Pada situasi dimana kontrol yang sangat ketat dibutuhkan maka metode token economy menjadi metode intervensi yang baik.

Bertolak dari pendapat tersebut, maka token economy adalah suatu cara untuk penguatan tingkah laku yang ditujukan seorang anak yang sesuai dengan target yang telah disepakati dengan menggunakan hadiah untuk penguatan yang simbolik. Dalam token ekonomi tingkah laku yang diharapkan muncul bisa diperkuat dengan sesuatu yang diinginkan oleh anak, sehingga hasil perilaku yang diharapkan oleh kita bisa ditukar dengan sesuatu yang diinginkan oleh anak. Token ekonomi merupakan salah satu contoh dari perkuatan ekstrinsik yang menjadikan seseorang melakukan sesuatu untuk diraihnya yakni bisa meningkatkan perhatiannya baik dari tingkat tenasitas maupun dari tingkat vigilitas, tujuannya adalah mengubah motivasi yang ekstrinsik menjadi motivasi yang instrinsik, dengan cara ini diharapkan bahwa perolehan tingkah laku yang diinginkan dapat menjadi ganjaran untuk memelihara tingkah laku yang baru.

\section{Aturan dan Pertimbangan Token Economy}

Agar efektif penerapan token economy perlu memahami beberapa aturan dan pertimbangan. Aturan-aturan dan pertimbangan tersebut antara lain :

a. Hindari Penundaan

Keunggulan Token Economy diperoleh dari pemenuhan persyaratan efektivitas pengukuhan, ialah pemberian pengukuhan dilakukan seketika setelah perilaku-perilaku sasaran muncul. Meskipun pengukuh yang sebenarnya baru dapat diberikan kemudian, tetapi token-token mewakili, menandai, merupakan isyarat atau merupakan symbol, bahwa sebagian pengukuh idaman telah ada ditangan subyek. 


\section{b. Berikan Token Secara Konsisten}

Telah dibicarakan pada uraian terdahulu, bahwa pemberian pengukuh yang terus-menerus (continuous) mempercepat peningkatan perilaku sasaran. Pada program ini, setiap kali perilaku yang telah disetujui dilaksanakan, secara konsisten diberi imbalan token.

c. Memperhitungkan Kuantitas

Perlu direncanakan agar banyaknya token yang akan diterima cukup untuk ditukar dengan pengubah idaman. Token yang terlalu banyak atau dihargai terlalu tinggi, akan menimbulkan kejenuhan. Sebaliknya, bila token dihargai terlalu rendah, sehingga program berjalan terlalu lama untuk dapat mencapai pengukuh idaman, maka subyek akan enggan berusaha memperoleh token.

d. Persyaratan Hendaknya Jelas

Aturan yang jelas mudah diikuti.Lebih baik lagi bila subyek diajak berdiskusi mengenai aturan-aturan dan persyaratan untuk memperoleh token. Kekeliruan-kekeliruan karena salah pengertian hendaknya segera dijelaskan. Demikian juga peringatan dengan symbol-simbol dan dukungan perlu diberikan agar subyek ingat bahwa program token masih berjalan (ini terutama diperlukan bila jarak memperoleh kepingan agak lama)

Contoh : Bagi seorang anak lemah mental. Hari-hari pertama ia belajar menyetrika, persyaratan mendapatkan token ialah bila ia sudah melicinkan satu pakaian dan memimdahkan ketempat pakaian licin ditumpuk. Program selanjutnya, ia baru mendapat token bila pakaian sudah dilipat, dan dipindahkan ke tempat pakaian terlipat ditumpuk. Tergantung pada daya faham dan ketrampilannya, tugas suatu program perlu dimulai dan dikembangkan

e. Pilih Pengukuh Yang Macam dan Kualitasnya Memadai Agar pengukuh idaman yang ditawarkan efektif, perlu dicocokkan macam dan kualitasnya dengan situasi dan kondisi subyek, Bermacam-macam pengukuh idaman dapat digunakan : berbagai 
benda, berbagai aktivitas yang cocok dengan suasana maupun yang dibuat-buat (artificial). Misalnya suatu program token dilaksanakan bagi anak-anak sekelas waktu pelajaran menggambar. Pengukuh idaman dapat saja tanpa nonton sirkus, yang tidak ada hubungannya dengan pelajaran menggambar. Namun demikian, acara artificial semacam ini jangan dipakai dahulu, bila ada acara yang lebih wajar dengan suasana program yang ditumpanginya. Pemilihan pengukuh idaman juga perlu memperhatikan masalah etika dan persetujuan masyarakat

f. Kelancaran Pengadaan Pengukuh Idaman

Perlu dipikirkan cara-cara pengadaan pengukuh, sebab banyak program token terbentur pada pengadaanpengukuh idaman ini. Tanpa pengukuh idaman yang "berharga",token sebagai pengukuh akan tidak efektif. Berbagai jalan harus ditempuh : mengumpulkan dan atau barang dari orang tua murid, dari dermawan, dari perusahaanperusahaan, bila ini program untuk sekelompok anak.

g. Pemasaran Pengukuh Idaman

Tidak berbeda dengan pemasaran barang didunia ekonomi tertutup, maka pemasaran pengukuh idaman perlu memperhitungkan hokum penawaran dan permintaan. Makin banyak permintaan suatu barang/aktivitas, makin dapat dipasang harga tinggi nilai tukarnya. Artinya pengukuh yang banyak peminatnya berharga lebih tinggi daripada pengukuh yang tidak banyak minatnya. Demikian juga bila sempit pilihan yang disediakan, maka tinggi jumlah peminatnya darpada bila disediakan pilihan yang luas.

"Harga" pengukuh ini dapat diubah-ubah. Misalnya suatu saat bermain keneker lebih berharga daripada bermain bola takrow, atau sebaliknya.

h. Jodohkan Pemberian Token dengan Pengukuh Sosial Positif Bila aktivitas/tindakan social positif telah efektif sebagai pengukuh, tentu tidak dibutuhkan program token. Salah satu tujuan yang harus 
dicapaidalam penggunaan token adalah agar subyek dapat berpindah dari pengukuh token ke pengukuh social. Karena itu pemberian token hendaknya bersama-sama dengan pengukuh social."Nah" begitulah. Kamarmu sudah kau benahi. Ini Tokenmu" dengan menunjukkan muka senang.

Dengan merencanakan memasang token dengan pengukuh social positif ini, juga melatih pengelola subyek untuk member penghargaan pada perilaku subyek. Ada kemungkinan sebelum program token berjalan, pengelola subyek kurang member penghargaan/pengakuan terhadap usaha subyek, tetapi mencela bila subyek tidak berusaha. Jadi program token dapat mendidik ketrampilan social pengelola maupun subyek.

i. Perhitungan Efeknya Terhadap Orang Lain

Teman sebaya,saudara kandung, teman sekamar (dilembaga perawatan) akan iri bila salah satu diantara mereka mendapat perlakuan istimewa. Karena itu perlu diusahakan agar mereka ikut membantu subyek memperoleh token, yang bila sampai jumlah tertentu seluruh kelompok akan ikut menikmati pengukuhnya. Namun perlu diajaga, agar mereka tidak mendorong terlalu keras atau mengancam subyek.

j. Perlu persetujuan Berbagai Pihak

Pelaksanaan program token mengganggu dan mericuhi acara yang ditumpanginya.Karena itu perlu izin pelaksanaannya dari orang tua, guru, kepala sekolah dan orang-orang lain yang mengelola program yang ditumpangi. Gangguan ini timbul karena kadang-kadang seubyek terlalu banyak mencurahkan perhatian pada program token sehingga tugas-tugas lain terganggu.

Pemberian benda sebagai imbalan juga sering tidak disetujui dengan anggapan mendidik anak jadi materialistis.

k. Perlu Kerjasama Subyek 
Program sulit berhasil bila tidak ada komunikasi dengan subyek.Makin jelas aturan main, makin setuju subyek pada program yang akan dilaksanakan,makin lancer pelaksanaan program dan makin efektif hasilnya.

Bagi anak-anak bentuk token yang menarik dapat menambah gairah mengumpulkan. Pengukuhan idaman dapat direklamekan dengan gambar-gambar untuk mengingatkan dan memikat subyek agar lebih giat berusaha.

Contoh program token didunia usaha adalah sebagai berikut: Suatu perusahaan yang mempunyai banyak anak usaha dan mencakup beberapa bidang usaha, misalnya dari took serba ada sampai penjualan bahan bangunan, mereklamekan diri bahwa mereka member hadiah satu meterai biru untuk pembelian seharga seribu rupiah. Mereka menyediakan album meterai yang menarik dan menyediakan buku catalog hadiah idaman. Misalnya satu album disediakan untuk menempelkan 200 meterai. Buku catalog menawarkan berbagai benda dengan nilai tukarnya, Misalnya : satu lampu duduk berharga 3 album, satu jam dinding berharga 7 album, dan sebagainya. Pemberian hadiah meterai biru ini berlaku bertahun-tahun, sehingga orang dapat menabung untuk mendapatkan lemari es dari album meterainya. Dengan demikian, orang akan berbelanja di took-toko atau perusahaan yang memberikan meterai biru ini.(perlu pengawasan terhadap pemalsuan meterai)

1. Perlu Latihan Bagi Pelaksana

Bila pelaksanaan program diserahkan kepada guru, orang tua, perawat atau orang lain, maka pelaksanaan perlu mendapat latihan-latihan dan pengetahuan yang diperlukan.

m. Perlu Pencatatan

Pencatatan cermat mengenai frekuensi perilaku sasaran dan perilaku lain perlu dilakukan. Selain ini mungkin dibutuhkan sebagai pertanggung jawaban, juga untuk mendeteksi keberhasilan program. 
Bila program tidak berhasil mencapai sasaran, perlu dilakukan perubahan bahkan mungkin dihentikan.

n. Kombinasi Dengan Prosedur Lain.

Programtoken dapat dikombinasikan dengan program lain, seperti denda dan penyisihan. Meskipun dapat meningkatkan efektifitas, kombinasi dengan program yang menggunakan stimulus eversif perlu pertimbangan mengenai efek sampingnya.

Misalnya, yang paling menyusahkan dalam mengelola Tining dan Aji ialah bila mereka berebut. Maka dalam program token untuk mereka berdua ditetapkan : siapa yang merebut hak/milik orang lain (tempat duduk, mainan, giliran dan lain-lain yang biasa mereka perebutkan) akan didenda 2 meterial

o. Follow Up : Penundaan Pengukuhan

Bila program tokentelah berhasil meningkatkan perilaku, sedang pengukuh social belum dapat menggantikan keseluruhan program token, maka perlu diadakan latihanpenundaan pemberian token. Ini mirip dengan praktek pemberian upah mingguan. Misalnya dalam lembaga perawatan, subyek harus membersihkan kamar, mengatur tempat tidur, mandi dan merapihkan diri sebelum mendapat sejumlah token, pujian dan makan pagi. (Makan pagi tidak dihitung sebagai pengukuh, sebab memaksa seseorang untuk puasa dianggap kurang etis. Tetapi, makan pagi dapat merupakan batas waktu).Jadi pemberian pengukuh tidak seketika setelah suatu perilaku dijalankan.

\section{Langkah-Langkah Token Economy}

Langkah-langkah implementasi token economy

a. Menentukan perilaku target

Semakin homogeny individu kelompok yang akan dikenai token economy, maka akan semakin mudah menstandardisasikan aturanaturan yang berlaku dalam token economy.

b. Mencari garis 
Yakni memperoleh data sebelum melakukan penanganan, biasanya melalui pengamatan selama dua minggu terhadap perilaku target. Sesudah program dimulai, kita bias membandingkan data dengan data yang diperoleh saat menentukan garis basal, sehingga dapat menentukan efektifitas program.

c. Memilih back up reinforcer

Perlu diperhatikan bagaimana karakteristik peserta program dan apa saja kira-kira barang yang dibutuhkannya. Barang yang menjadi pengukuh pendukung haruslah barang yang dapat digunakan atau consumable. Perlu diperhatikan pula tempat penyimpanan dan dana yang dibutuhkan untuk melaksanakan program.

d. Memilih tipe token yang akan digunakan.

Secara umum tipe token haruslah menarik, ringan, mudah dipindahkan, tahan lama, mudah dipegang dan tidak mudah dipalsukan. Beberapa contoh yaitu stiker, keeping logam.koin,check-mark, Poin, poker chip, stempel yang dicap dibuku, tanda bintang, kartu dll.

e. Mengidentifikasi sumber-sumber yang bisa membantu.

Beberapa sumber yang bias membantu adalah staf, relawan, mahaanak, residen, orang yang akan dikenai token itu sendiri.

f. Memilih lokasi yang tepat.

Token dapat diberikan dimana saja, asal diberikan setelah perilaku target muncul

g. Menyiapkan manual/pedoman token economy pada klien dan staf

\section{B. Kemandirian}

\section{Pengertian Kemandirian}

Desmita (2011: 185) mengungkapkan pengertian kemandirian sebagai kemampuan untuk mengendalikan dan mengatur pikiran, perasaan dan tindakan sendiri secara bebas serta berusaha sendiri untuk mengatasi perasaan-perasaan malu dan keragu-raguan. Lebih dari itu Desmita menjelaskan bahwa kemandirian biasanya ditandai dengan kemampuan 
menentukan nasib sendiri, kreatif dan inisiatif, mengatur tingkah laku, bertanggung jawab, mampu menahan diri, membuat keputusan sendiri, serta mampu mengatasi masalah tanpa ada pengaruh dari orang lain.

Menurut Robert Havighurst dalam Desmita (2011: 186), kemandirian dibedakan menjadi empat bentuk antara lain sebagai berikut. Pertama, kemandirian emosi, yaitu kemampuan mengatur emosi sendiri dan tidak tergantungnya kebutuhan emosi pada orang lain atau orang tua. Kedua, kemandirian ekonomi, yaitu kemampuan mengatur ekonomi sendiri dan tidak tergantungnya kebutuhan ekonomi pada orang lain atau orang tua. Ketiga, kemandirian intelektual, yaitu kemampuan untuk mengatasi berbagai masalah yang dihadapi. Kemandirian intelektual ini merujuk pada kemampuan berpikir, menalar, memahami beragam kondisi, situasi dan gejala-gejala masalah sebagai dasar usaha mengatasi masalah. Sedangkan yang keempat, kemandirian sosial, yaitu kemampuan untuk mengadakan interaksi dengan orang lain atau kemampuan untuk berani secara aktif membina relasi sosial dan tidak tergantung pada aksi orang lain.

\section{Tingkatan dan Karakteristik Kemandirian Anak}

Desmita (2011: 187-188) memaparkan tingkatan dan karakteristik kemandirian beradasarkan pendapat Lovinger ke dalam enam tingkatan sebagai berikut. Tingkatan pertama adalah tingkat impulsif dan melindungi diri. Ciri-cirinya antara lain: peduli terhadap kontrol dan keuntungan yang dapat diperoleh dari interaksinya dengan orang lain; mengikuti aturan secara spontanistik dan hedonistik; berpikir tidak logis dan tertegun pada cara berpikir tertentu (stereotype); cenderung melihat kehidupan sebagai zero-sum games; dan cenderung menyalahkan dan mencela orang lain serta lingkungannya.

Tingkat kedua adalah tingkat konformistik. Ciri-cirinya: peduli terhadap penampilan diri dan penerimaan sosial; cenderung berpikir stereotype dan klise; peduli akan konformitas terhadap aturan eksternal; bertindak dengan motif yang dangkal untuk memperoleh pujian; menyamakan diri dalam ekspresi emosi dan kurangnya intospeksi; perbedaan kelompok didasarkan 
atas ciri-ciri eksternal; takut tidak diterima kelompok; tidak sensitif terhadap keindividualan; dan merasa berdosa jika melanggar aturan.

Tingkat ketiga adalah tingkat sadar diri. Ciri-cirinya: mampu berpikir alternatif; melihat harapan dan berbagai kemungkinan dalam situasi ; peduli untuk mengambil manfaat dari kesempatan yang ada; menekankan pada pentingnya memecahkan masalah; memikirkan cara hidup; dan penyesuaian terhadap situasi peranan.

Tingkatan keempat adalah tingkat saksama (conscientious). Ciri-cirinya antara lain: bertindak atas dasar nilai-nilai internal; mampu melihat diri sebagai pembuat pilihan dan pelaku tindakan; mampu melihat keragaman emosi, motif dan perspektif diri sendiri maupun orang lain; sadar akan tanggung jawab mampu melakukan kritik dan penilaian diri; peduli akan hubungan mutualistik; memiliki tujuan jangka panjang; cenderun melihat peristiwa dalam konteks sosial; dan berpikir lebih kompleks dan atas dasar pola analitis.

Tingkatan kelima adalah tingkat individualitas. Ciri-cirinya: peningkatan kesadaran individualitas; kesadaran akan konflik emosional antara kemandirian dan ketergantungan; menjadi lebih toleran terhadap diri sendiri dan orang lain; mengenal eksistensi perbedaan individual; mampu bersikap toleran teradap pertentangan dalam kehidupan; membedakan kehidupan internal dengan kehidupa luar dirinya; mengenal kompleksitas diri; dan peduli akan perkembangan dan masalah-masalah sosial.

Tingkatan keenam adalah tingkat mandiri. Ciri-cirinya antara lain: memiliki pandangan hidup sebagai suatu keseluruhan, cenderung bersikap realistic dan objektif terhadap diri sendiri dan orang lain; peduli terhadap pemahaman abstrak, seperti keadilan sosial; mampu mengintegrasikan nilainilai yang bertentangan; toleran terhadap ambiguitas; peduli akan pemenuhan diri (self-fulfilment), ada keberanian untuk menyelesaikan konflik internal; responsif terhadap kemandirian orang lain; sadar akan adanya saling 
ketergantungan dengan orang lain; dan mampu mengekspresikan perasaan dengan penuh keyakinan dan keceriaan.

\section{Faktor-Faktor Kemandirian Pada Anak}

Kemandirian pada anak muncul tanpa selalu dapat diprediksi melalui usia, namun dapat dilihat ketika anak sudah mulai memiliki keinginan sendiri, atau dengan kata lain tingkatan usia tidak mesti berpengaruh terhadap kemandirian anak. Ada anak yang usianya sudah beranjak dewasa atau bahkan sudah dewasa pun masih belum memiliki sikap mandiri. Namun ada pula anak yang usianya masih sangat dini sudah memiliki sikap yang mandiri. Hal ini ditentukan oleh beberapa faktor seperti yang diungkapkan Dra. Mayke Sugianto Tedjasaputra, M. Si dalam Arbya (2011) berikut.

Pertama, faktor bawaan, dimana ada anak yang berpembawaan mandiri, ada yang memang suka menikmati jika dibantu orang lain. Kedua, faktor pola asuh yang memungkinkan anak berpembawaan mandiri menjadi tidak mandiri karena sikap orang tua yang selalu membantu dan melayani. Ketiga, faktor kondisi fisik anak, misalnya anak yang kurang cerdas atau memiliki penyakit bawaan, bisa saja diperlakukan lebhih "istimewa" ketimbang saudara-saudaranya sehingga menjadikan anak tidak mandiri. Keempat, urutan kelahiran, contohnya anak sulung cenderung lebih diperhatikan, dilindungi, dibantu, apalagi orang tua belum cukup berpegalaman. Anak bungsu cenderung dimanja, apalagi bila selisih usianya cukup jauh dari kakaknya.

\section{METODE PENELITIAN}

Penelitian ini menggunakan pendekatan deskriptif eksperimen. Dalam penelitian ini pendekatan deskriptif digunakan untuk menjelaskan bagaimana tingkat kemandirian pada anak usia TK. Sedangkan pendekatan eksperimen digunakan untuk menjelaskan bagaimana tingkat efektifitas teknik token economy untuk meningkatkan kemandirian anak TK Kartika VI-21. Pada pendekatan eksperimen ini peneliti akan menggunakan teknik one shot case study, dimana 
terdapat suatu kelompok yang diberi treatment/perlakuan dan selanjutnya diobservasi hasilnya.

Populasi dalam penelitian ini adalah anak TK Kartika IV-21 Madiun tahun akademik 2012-2013, yang berjumlah 46 orang anak. Sedangkan sampel penelitian berjumlah 20 anak. Penetapan anggota sampel penelitian ini dilakukan dengan teknik "purposive samping".

Untuk memperoleh data tentang efektifitas penerapan teknik token economy untuk meningkatkan kemandirian anak TK Kartika IV-21, akan menggunakan instrument sebagai berikut :

1. Lembar Observasi

Lembar observasi yang akan digunakan dalam penelitian ini untuk mengetahui kemandirian anak selama setelah diterapkan teknik token economy. Lembar observasi ini mengamati beberapa indikator antara lain:

a. Anak berani maju didepan kelas pada saat ditunjuk oleh guru

b. Anak mampu menggambar dan mewarnai sendiri tanpa bantuan guru

c. Anak mampu menjiplak, menggunting dan menempel sendiri

d. Anak bertanggungjawab dengan apa yang diperbuatnya.

2. Wawancara

Wawancara dilakukan kepada para guru sekolah dan orang tua anak untuk mengetahui kemandirian anak yang sering ditunjukkan.

Penelitian ini menggunakan metode penelitian single case study yang bertujuan untuk mengetahui perubahan perilaku setelah diterapkan teknik token economy. Dalam penelitian ini metode pengumpulan data menggunakan teknik observasi dan wawancara (interview). Dalam menganalisis data menggunakan analisis non-statistik berupa grafik.

\section{PEMBAHASAN}

Berdasarkan penelitian awal yang dilakukan di TK Kartika IV-21 Kota Madiun diperoleh gambaran bahwa anak usia TK di TK Kartika IV-21 Kota 
Madiun cenderung menunjukkan perilaku mandiri yang rendah. Hal ini terlihat dari hasil observasi yang dilakukan peneliti yang menunjukkan prosentase sebesar $22,12 \%$ dan juga wawancara dengan guru dan orang tua anak.

Berdasarkan hasil observasi awal yang dilakukan sebanyak 3 kali pada tanggal 29 Maret, 12 April dan 26 April 2013 diperoleh data bahwa perilaku kurang mandiri yang sering muncul pada anak TK Kartika IV-21 Kota Madiun diantaranya adalah antara lain pada saat menyanyi di depan kelas masih kelihatan takut dan malu, mengerjakan tugas seperti menggunting, menempel, menjiplak, menggambar, mewarnai masih perlu bantuan dari gurunya.

Untuk meningkatkan kemandirian anak maka diterapkan teknik token economy yang dilakukan mulai dari tanggal 1 Mei sampai dengan 21 Juni 2013 dan mendapatkan hasil terdapat peningkatan kemandirian anak dengan prosentase $41,35 \%$ yang dikategorikan cukup mandiri. Rincian peningkatkan kemandirian anak dapat dilihat dalam tabel 1.1

Tabel 1.1. Rekapitulasi Hasil Penelitian Kemandirian Anak

\begin{tabular}{|c|l|c|}
\hline No & \multicolumn{1}{|c|}{ Penelitian } & Prosentase \\
\hline 1 & Observasi awal & $22,12 \%$ \\
\hline 2 & Setelah penerapan teknik token economy & $41,35 \%$ \\
\hline
\end{tabular}




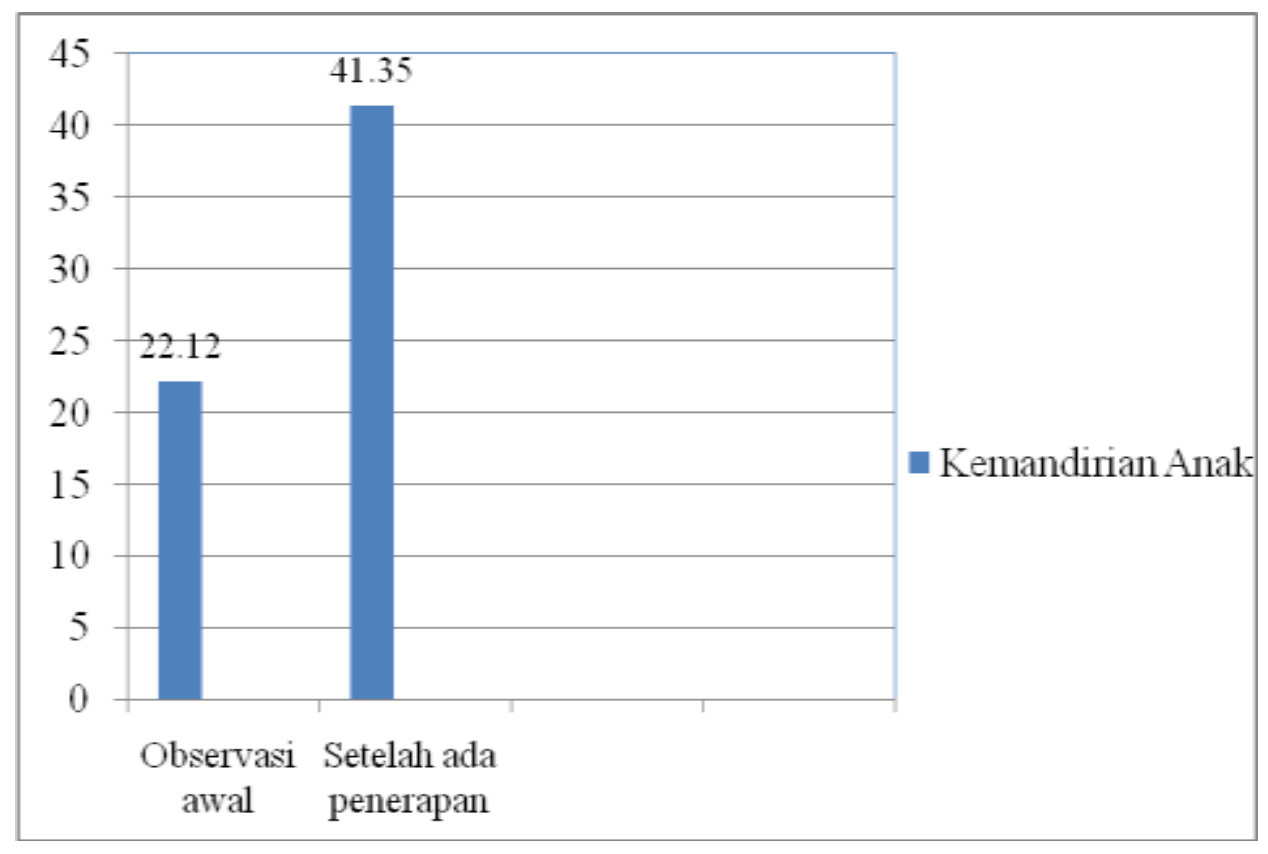

Grafik 1.1. Prosentase Rekapitulasi Hasil Penelitian

Dari grafik 1.1 menunjukkan bahwa kemandirian anak mulai dari observasi awal sampai penerapan teknik token economy yang pertama terjadi kenaikan pada setiap indikator. Hal ini menunjukkan bahwa penerapan teknik token economy dapat meningkatan kemandirian anak TK Kartika IV21 Kota Madiun.

\section{SIMPULAN}

Dalam penelitian ini, peneliti bertujuan untuk mengetahui sejauh mana peningkatan kemandirian anak setelah diterapkan Teknik Token Ekonomy pada anak TK Kartika IV-21 Kota Madiun. Token Ekonomy pemberian satu kepingan (atau satu tanda, satu isyarat) sesegera mungkin setiap kali setelah perilaku sasaran muncul. Kepingan-kepingan ini nantinya dapat ditukar dengan benda atau aktivitas pengukuh yang diingini oleh subyek.

Berdasarkan hasil penelitian dan analisis data yang telah dilakukan ada peningkatan kemandirian anak, pada awal sebelum diterapkan teknik Token Ekonomy prosentase kemandirian anak sebesar 22,12\%, sedangkan setelah diterapkan teknik Token Ekonomy kemandirian anak meningkat menjadi 41,35\%. 
Maka dapat disimpulkan bahwa teknik Token Ekonomy dapat meningkatkan kemandirian anak TK Kartika IV-21 Kota Madiun.

Hasil penelitian ini memberikan gambaran bahwa penerapan teknik token economy dapat meningkatkan kemandirian anak. Agar proses belajar mengajar dapat memperoleh hasil yang optimal, maka peneliti menyarankan: 1) kepada Guru, hendaknya dapat mempertimbangkan penerapan teknik token economy dalam kegiatan belajar mengajar; dan Teknik token economy memerlukan banyak persiapan pada saat penerapannya, maka diperlukan suatu perencanaan dan pengelolaan waktu yang matang oleh guru; 2) kepada Peneliti lain yang menggunakan teknik token economy dalam kegiatan pembelajaran, hendaknya peneliti tersebut mengambil reinforcement atau token yang lain dan menerapkan teknik token economy ini pada jenjang pendidikan Sekolah Dasar. Hal ini bertujuan untuk mengetahui apakah penerapan teknik token economy memberikan hasil yang lebih baik atau tidak. Keterbatasan penelitian yaitu teknik token economy ini hanya terbatas pada satu kelas saja. Sehingga ada atau tidaknya peningkatan kemandirian anak hanya dapat dilihat dari hasil observasi kemandirian anak dari satu kelas saja.

\section{DAFTAR PUSTAKA}

Arikunto, S. 2002. Prosedur Penelitian Suatu Pendekatan Praktik . Jakarta : PT. Rineka Cipta

Balson, Maurice. 1993. Bagaimana Menjadi Orang Tua yang Baik. Jakarta: Bumi Aksara.

Budi Purwoko dan Pratiwi, Titin Endah. 2007. Pemahaman Individu Melalui Teknik Non Tes. Surabaya: Unesa University Press

Desmita. 2011. Psikologi Perkembangan Peserta Didik. Bandung: PT Remaja Rosdakarya.

Edi Purwanta. 2012. Modifikasi Perilaku. Yogyakarta: Pustaka Belajar

Fatimah, Enung. 2008. Psikologi Perkembangan (Perkembangan Peserta Didik). Bandung: CV Pustaka Setia.

Gunarsa Singgih. 2003. Konseling dan Psikoterapi. Jakarta: BPK

Hall, C S. 1993. Teori Sifat dan Behavioristik. Yogyakarta: Kanisius

Henny Indeswari. 1993. Analisis Pengubahan Tingkah Laku. Malang: IKIP Malang Press

Hetty Rahmawati. 2003. Modifikasi Perilaku. Yogyakarta: Kanisius

John W. Santrock.1995. Life Span Development . Jakarta: Erlangga

Kartini, Kartono. 1996. Psikologi Umum. Bandung: Mandar Maju 
King, Laura A. 2010. Psikologi Umum: Sebuah Pandangan Apresiatif. Jakarta: Penerbit Salemba Humanika.

Latipun. 2006. Psikologi Konseling. Malang: UMM Press

Martin, Garry \& Joseph Pear. 1983. Behavior Modification.New Jespey.Prentice Hall: Englewood Cliffs

Sobur, Alex. 1986. Komunikasi Orang Tua dan Anak. Bandung: Angkasa.

Soetarlinah Soekadji. 1983. Modifikasi Perilaku Sehari-hari dan penerapan Profesional. Yogyakarta: Liberty

Stephen Palmer. 2011. Konseling dan Psikoterapi. Yogyakarta: Pustaka Belajar

Sutrisno Hadi. 2000. Statistik Jilid II. Yogyakarta: Yayasan penerbit fakultas Psikologi Universitas Gadjah Mada

Arbya, Nety. 2011. "Membentuk Kemandirian Anak". (Online) http://keluargasehat.wordpress.com. (diakses 29 Mei 2012).

Indonesia, Blogger. 2010. "Teori Tentang Bimbingan Orang Tua". (Online) http://heruid.blogspot.com/2010/02/teori-tentang-bimbingan-orang-tua.html. (diakses 9 Juni 2012).

Simanjuntak, Lisber. 2011. "Menanamkan Kemandirian pada Anak Sejak Usia Dini".

(Online) http://www.bpplsp-reg1.go.id/buletin/read.php?id=74\&dir=6\&idStatus=0. (diakses 29 Mei 2012).

Sourie, Julak. 2012. "Peranan Orang Tua dalam Mengembangkan Kemandirian Anak". (Online) http://julak-net.blogspot.com/2012/04/peranan-orangtuadalammengembangkan.html. (diakses 29 Mei 2012).

Trisni, Inda. 2009. "Melatih Kemandirian Anak". (Online) http://harikuakhiratku.blogspot.com/2009/07/melatih-kemandiriananak.html. (diakses 29 Mei 2012).Corey, Gerald. 1988. Teori dan Praktek Konsel 